San Antonio Review • San Antonio Review (Volume V | Spring 2021)

\title{
Berard Reviews the Next World War
}

Peter Berard ${ }^{1}$

$\mathbf{1}_{\text {San Antonio Review }}$

Published on: Mar 31, 2021

DOI: $10.21428 / 9 b 43 c d 98.04 a e 6 e a c$

License: Creative Commons Attribution 4.0 International License (CC-BY 4.0). 
Book Reviewed:

2034: A Novel of the Next World War

Elliot Ackerman and James Stavridis

Penguin Press

2021

320 pp

$\$ 27.00$

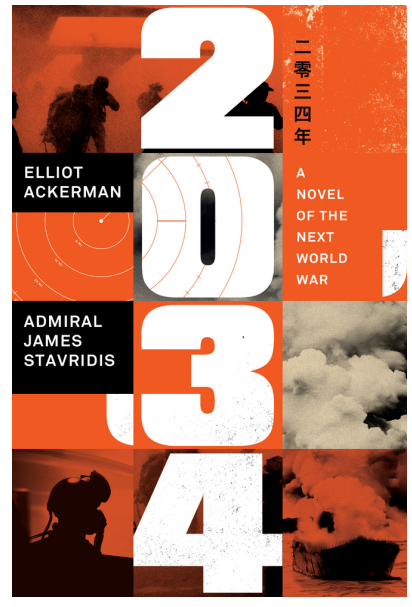

The tradition of war prognostication in novel form that extends back at least as far as H.G. Wells and Sax Rohmer is long - can it be called honorable? I suppose it depends on whether you think the two genres from which it most heavily draws - pornography and advertisement - are honorable. That might sound like a snide dig, but as far as I am concerned, it is an open question. People like masturbating; people like to know what products are available to buy. Who's to say helping them out with those tasks isn't honorable? It's usually the unswerving devotion to getting off that tangles up the pornographer or the advertiser. The disregard for truth, cultural sensitivities and the like in pursuit of their goals gets them in trouble in the short term. In the long term, they encounter the troubled waters of critical reception and market segmentation tough waters for anyone, especially someone just trying to make a buck. That's art for you.

The pornographic element of novels predicting and playing out near-future wars existed in the likes of Rohmer's race-war fantasies but came into its current form during the Cold War. Nuclear strategist Herman Kahn referred to the world-ending nuclear war predicted by many as the "wargasm." He meant it as a derisive term, part of his effort to undermine the paradigm of mutually assured destruction in favor of his concept of "winnable" nuclear war, but the word has truth to it. The Cold War constituted a long, long build up, especially for westerners eager to fight. Fantasies of the nuclear "wargasm" and its aftermath were one popular way to cope with the tension, but ultimately it was too nihilistic for people who really wanted a good old fashioned war, not a sudden blow-up followed by all kinds of pesky, tedious rebuilding.

The “wargasm" fantasy wasn't good advertising for anybody, either. Fantasies of a more-or-less conventional Soviets vs NATO war both delivered a more refined appeal 
to militaristic bloodlust and an advertising platform for various Cold War strategies and their attendant expensive toys. By the time the 1980s and Reagan's "second Cold War" was in full swing, the genre produced its two standout hits: John Hackett's The Third World War and Tom Clancy's Red Storm Rising. Hackett was a British general with a long service record, Clancy was an American insurance man with no military service. Perhaps due to these differences, Hackett's work is darker and feels more realistic, whereas Clancy throws in a lot of American derring-do saving the day. But both works actively promoted the idea that the U.S. and NATO were seriously vulnerable to the Soviet Union and needed to invest more in defense spending and "forward defense," and helped sell the concept by showing off all the cool stuff the NATO militaries can and should have ("boys and toys" was Clancy's real speciality).

They got everything wrong, except, perhaps, for the central fact that Soviet armored columns could probably have punched a good-sized hole in Western European defenses had they been so inclined to a last joy-ride for organized warfare before the superpowers blasted the world back to the Stone Age. The Soviets were a decaying, scared power with a leadership class overwhelmingly invested in dying in bed before their system collapsed. But what does that matter? Defense contractors and hawkish politicians got their ad time. "Serious" people and open "war nerds" both could read and enjoy the pornographic element of release these books provided under the guise of edification. No one loses!

With the end of the Cold War, the genre entered a remission period but never went away. Dreams are funny that way. As conventional interstate armed conflicts became less and less relevant after the "End of History," two equal and opposite strains of nearfuture war fantasy cropped up. Call the American far-right "participant observers" in the crackup of consensus sensibilities and "tribalizing" of the period - they dreamed of internal war within the United States, a funhouse mirror version of the insurgency/"unconventional" wars that dominate the military news of our time. From The Turner Diaries to Ben Shapiro's attempts at thriller fiction, this fantasy has become more mainstream as have the tribal hates of white America.

The other strain warned us, in the crackpot-realist mode of American centrism, that conventional battle, the big Fulda Gap blowup, was going to come back - the Russians were going to bum-rush the Czech Republic! We'd need to occupy Mexico because . . . drugs! And, always, an effort to put China in the villain spot Russia once held. Internal war fantasists usually throw in some foreign intervention, just to make the treason charges sizzle, but for real foreign war action you need the centrists. At first, this was 
a bipartisan affair, with Republican Tom Clancy trying his hand at China stuff in the aughts, but as right-wing attention turns inward, Democrats and what could broadly be called "liberals" now own this space.

Exhibit A: the new novel, 2034, by Marine veteran and novelist Elliot Ackerman and a former head of his alma mater, the Fletcher School of Foreign Affairs at Tufts, retired four-star U.S. Navy admiral (now working for Carlyle Group) James Stavridis. These aren't your father's militarists: they're sensitive, worldly, learned (or highly educated anyway) meritocrats, equally at home on the bridge of a carrier or on The Colbert Show. Think about the profile David Petraeus cut before he exploded his career and you're not far off. These are the writers who are going to explain the dangers of the coming decades to the reading public.

Emphasis on "dangers." Clancy, Hackett, Wells, Rohmer - there was joy there, a sense of fun. There's no fun to be had in war between China and the U.S. in 2034. The Obamican audience Penguin has lobbed this book at doesn't permit itself to publicly enjoy bloodshed, restricting that particular human drive to furtively streamed UFC fights and video games. What do these people let themselves enjoy publicly? Fusion cuisine? Self-satisfaction? Who knows?

John Hackett, the smartest and most entertaining of the Cold War war-what-if novelists, was smart enough to restrict most of his action to the European theater, where you could get a good look at everyone duking it out with all the cool toys. He threw a few bones to naval war fans and Third World revolt paranoiacs (he had Nigeria trying it on with apartheid South Africa in open battle, a pretty big laugh) but knew where the action was. Clancy mostly followed suit in Red Storm Rising. The Soviets in the Cold War novels typically had some dumb crisis (fair enough, their nod to the Soviet system's decrepitude) that was little more than an inciting incident, a rationale for the fight everyone was there for. In 2034, China has a Plan. Ackerman and Stavridis take almost the entirety of Eurasia and the Pacific Ocean as their canvas. This means geopolitics, grand strategy, and there, you might have the answer to where the joy is supposed to be.

Our action begins in the South China Sea and the Persian Gulf, simultaneously. The two protagonists we meet in these respective locations also represent two different strains of the Best America Has To Offer. In the South China Sea we have Commander Sarah Hunt, meritocrat, would-be SEAL, an all-around "girlboss" and one mission away from retirement, to boot. In the Gulf, we've got Wedge Mitchell, fourth-generation Marine pilot, representative of the "safe" Red America, our hereditary military 
Kshatriya caste. $\underline{1}$ Hunt is sailing her small flotilla on a "freedom of navigation" patrol when she runs into a fishing trawler on fire. It's not her mission to help out stranded craft - she's supposed to radio them in - but she senses something is wrong and so goes in. Lo and behold, it's a spy ship! Wedge, for his part, is testing out the stealth capacity on his F-35 (guess they got past the "boondoggle death trap" stage of development on that particular turkey) in Iranian airspace when all of a sudden mean Iranian hackers are flying his plane for him! At the same time!

Sino-Iranian mischief is afoot, but if there was any criticism of the way the characters blithely walked into the traps set for them through disrespect for the sovereignty of other countries and sheer foolishness (Hunt's intuition is never vindicated), it flew over this reviewer's head. Moreover, the plan on the part of the Chinese isn't clear, either. They propose to trade the F-35 for their spy boat, but they know the U.S. will reject the deal, so . . . they'll sink the American ships? Or something? The Chinese and their Iranian and Russian pals are depicted as strategic masterminds one minute and incompetent blunderers the next.

None of the plans hold water. That'd be ok if $\underline{2034}$ delivered any other genre goods. It doesn't and, while failing to do so, produces the grim spectacle of establishment types slowly and painfully questioning certain aspects of establishment logic while still not quite "getting it." To wit: the toys. Hackett and Clancy amuse us with the many toys NATO and, to a lesser extent, the Warsaw Pact came up with to do each other in. They're fun, in a G.I. Joe-meets-Italian-futurism sense. To their credit, Ackerman and Stavridis get that many of these toys are basically extraordinarily expensive paperweights (though they weirdly whiff on the essential badness of the F-35, which even non-war-nerds know is garbage). This lesson has been taught by experience the two decades of counterinsurgency war where we have a difficult time bringing lowtech opponents to heel - and by tests like the notorious Millennium Challenge, a wargame where a Marine general playing as Iran sank a whole U.S. carrier fleet in a matter of minutes with swarms of cheap missiles. But there's too much money to turn away from our high-tech white elephants like aircraft carriers now.

Ackerman and Stavridis might get it about tech, but to use a term from a guy they'd probably find sympathetic, Robert Heinlein, they do not "grok" it. To wit, the U.S. Navy (this is a very Navy-centric book - the Army and Air Force barely enter into it) isn't beaten by low-tech. It's beaten by anti-tech- "offensive cyberwar" capacities unlike anything the world has ever seen. The Chinese and Iranians prove themselves capable of hacking literally anything digital. They can black out whole swaths of the seas from 
U.S. surveillance, hack an F-35 to fly without its pilot, so on and so on. This is an interesting concept, but the authors fail to make it work dramatically. The first time the Chinese do it in the South China Sea, it's a decent "oh, shit" moment. But then different players keep doing it. And the authors don't dramatize it. Dramatizing hacking is a notorious challenge in Hollywood, where the visual realities of boring computer work interfere, but surely Ackerman, who has written espionage novels, could have come up with something. Instead, "cyber" is just a magic wand those devious Asiatics wave around to mess with our weapon systems and then kick us while we're down.

So, there are no toys and no blood. Millions die, but the authors make the (probably correct) choice not to dwell on the gory details. So, what is there to enjoy? To say the characters are "cardboard cutouts" - well, that wouldn't be a problem in a genre that's half-porn and half-ad, would it? But these aren't really colorful cardboard cutouts even. The U.S. American characters represent various aspects of the liberal meritocracy (just to really seal the message, one of the American submarines involved is the USS Michelle Obama): the girlboss skipper, the manly-but-with-it Marine and the Indian-American policy wonk. There's an Iranian Revolutionary Guard general who goes from brutal and escalatory to sympathetic and deescalatory as the plot demands. There's a Chinese naval attaché who winds up in various convenient positions until he doesn't anymore. The authors do not succeed in raising the genre to "literary" merit through character work.

As best I can tell, the only pleasure on offer in 2034 is whatever pleasure can be found in "grand strategy." Out of the universe of high-flown nonsense our ruling class foists upon us in the guise of ideas, grand strategy might have the highest albedo. The grandiloquence of its pronouncements reflect off the rankness of its bullshit and thinness of its intellectual grounds like a summer moon in the country night sky. When an empire starts taking "grand strategy" seriously, as opposed to economic advantage or some other relatively sensible hermeneutics, that's a good sign said empire is on its way down. Ackerman and Stavridis mostly spare us the portentous remarks on human nature and the pseudo-erudite references to Xenophon, Grotius, et al. that usually pepper works of grand strategy. But the reduction of the world to power blocs (that roughly line up with "civilizations" a la Samuel Huntington) wrestling for "supremacy" as understood by upper-class nerds who associate lines on the map with reality . . . well, that's all there. 
Grand strategy also provides a way out of the narrative impasse the authors write themselves into. They need China to seriously threaten the U.S., both to have a novel and likely to further some "new Cold War" bullshit line they hold. They need the U.S. to hit back. Otherwise, there's no conflict. They also need to avoid all-out nuclear war this isn't some anti-war screed, for all its squeamishness. It'd also be good to work in that other big rising power into the mix (though they feel fine completely ignoring Western Europe and Latin America), and so, India comes to the rescue. India waves its magic-cyber-wand, positions its submarines just so, and tells China and the U.S. to knock it off, three nuked cities is enough. Shanghai gets nuked anyway - fog of war/ironic sacrifice for Wedge the American Man - but in the end, the war stops, and India becomes the big power. India - and the authors make clear this is an India made puissant by Modi - makes the decisive play on the big Risk board and that's all she wrote. We don't even get to see any fun diplomacy making it happen: the IndianAmerican wonk has family in high places in Modi's India and they fix it. The end.

A materialist reading of military history - one not restricted to "materialism" as in "let's control the trade routes," even grand strategists get that, I mean "materialist" as in understanding class society - shows that strategy and tactics often tail politics. Armored chivalry dominated the battlefields of Europe well after it made any sense because you couldn't tell the nobles that their preferred mode of fighting couldn't predominate. In our own time, interests made decreasingly relevant by technology, like the surface navy and manned combat aircraft, remain central to the U.S. arsenal due to money and institutional inertia.

More to the point of class, the ways in which the U.S. American bourgeoisie can make itself feel relevant in the world of war bifurcate, like so many things today do, along reactionary versus liberal lines. One way is to intensively exercise both body and latent sociopathy and become a special forces operator. Halfway sensible empires - the Romans, the Mongols, the British - typically hired out tasks like assassination, paying off local warlords, and long-range scouting to locals in whichever imperial locale because they're cheap and have local knowledge. We go the long way around the barn and expensively train Americans to do the same stuff, only to have them become celebrities or politicians a la Kyle/Luttrell/Greitens/Crenshaw, who go on to denounce things like participation trophies. On the liberal side, you can go to many years of school, get good grades, demonstrate "cultural competency" (take a semester abroad and really vibe with the international students on your dorm floor) and the command of buzzwords, maybe do a stint in the service to get extra cred, and then you get to play the "grand strategy" game. Your fatuous notions - three-quarters stereotype and one- 
quarter regurgitated theory mama-birded to you by some half-awake TA - get to take on civilizational importance on the big Risk board.

Anyone who's ever played Risk knows there are two ways to play: You can pile up pieces in Australia, or throw the stupid game away and play damn near anything else. The questionable historicism of Axis and Allies, the gleeful sociopathy of Diplomacyhell, Super Smash Brothers at least has an interesting culture attached to it anything (with the possible exception of Monopoly) is preferable. 2034 manages to be both horrifying and boring. The authors make much of China blinding the U.S. Navy with its magic cyber wand, but the U.S. it portrays is already blind - blinded by the idiocy of an elite that smells something afoot with those devious Chinese and knows something needs to be done. Something always needs to be done, in the flaggingly masculine imagination of the U.S. security elite. Have they ever considered that maybe, sometimes, doing nothing works?

That this book came out during a time of record-high attacks on Asians and AsianAmericans in the U.S., impelled by COVID-inspired racism and "new Cold War" bullshit, gives a real-life glimmer of evil to a book already characterized by wrongness. Typically, the authors allude to anti-Chinese racism as wrong, and show the characters eating at a (empty) Chinese restaurant, but if we stumbled into a war with China, let alone one where they fight us to a draw and we lose millions to nuclear attacks and India has to bail us out (threatening us in the process), empty restaurants would be the least of our worries. Pogroms and detainment would be in the cards. In that situation, fleeing to Australia wouldn't be enough. We'd have to flip over the Risk board and tell these people we're not playing their games anymore. The sooner we make clear they don't get to play with our lives this way, the better.

Peter Berard, Ph.D., a writer, historian and organizer in Watertown, Mass., is San Antonio Review's book review editor. Read more of his work at Melendy Ave. Review.

\section{Footnotes}

1. 
Kshatriya: a member of the second of the four great Hindu castes, the military caste. The traditional function of the Kshatriyas is to protect society by fighting in wartime and governing in peacetime.

$\underline{\underline{n}}$ 